\title{
GENDER ROLES IN THE UKRAINIAN MODERNISM FICTION LITERATURE OF THE 1920S
}

\section{Kavun L. I.}

\section{INTRODUCTION}

Forming a new philosophical and aesthetic paradigm of the early twentieth century, Ukrainian writers sought to comprehend an individual and the world through modern dimensions and relationships. One of the concepts that determined the essence of the aesthetically-artistic phenomenon of the literature of modernism was the confrontation of "patriarchal and contemporary ideas about the place and role of men and women in sociocultural processes, and about biological and social factors of gender identification".

The issue of gender receives an increased interest in the literary world of that time, specifically in the works by Ivan Dniprovsky, Arkady Lyubchenko, Mykola Khvylovy, and other prose writers of the second decade of the twentieth century. Modernist fiction is characterized through the reception of the relationship between man and woman as two different types of worldviews, two philosophies of being, the writers focus on interpersonal relationships, and the search of a partner and their place in the world. The interest in this theme was natural because the turn of the cultural epoch was marked by a comprehensive "re-evaluation of values", and the search for new ideas. The established values and normative ideas about the rights and opportunities of men and women have come to the background. The eternal passions that drive people's behavior (love, betrayal, disappointment, faith) are interpreted differently in comparison to traditional art.

After 1905, the reorganization of society stimulated not only the deepening of thoughts of love but also, it caused the restoration of sensual love. In addition, science (psychology, physiology, ethics, philosophy) has inspired different, even opposite views on love. Z. Freud emphasized the sexual nature of this feeling, and A. Babel considered the problem of gender in connection with socialist ideologists, in the fight against any inequality. Ukrainian modernists of the 1920s explored both the biological-irrational and social aspects of love.

${ }^{1}$ Агеєва В. Жіночий простір: Феміністичний дискурс українського модернізму. Київ : Факт, 2003. С. 5. 
The theme of love is viewed through the modern spirit in the prose of the 1920s. The writers are trying to make it clear, "what is love in general whether it is spiritual power, eroticism, which is in the opposition to sex, or whether love is nothing but sex itself?" 2 . Therefore, the image of a woman is perceived differently in the metatext of fiction in the 1920s. This is both an abstract woman (such as A. Lyubchenko's "The Nativity Play" heroine, or a woman named Maria in M. Khvylovy's "Arabesque"), and a specific woman who is put in her everyday historical and geographical living (as the heroes of "The Four Sabers", "Ship Master" Y. Yanovsky, or "Sanatorium Zone", "Sentimental Story" of M. Khvylovy or female images of the novel "Without Soil" by G. Epic, the story "Anathema" by I. Dniprovsky).

\section{Revision of Gender Stereotypes in Ukrainian Modernism in the 1920s}

The artistic representation of the problem of gender roles in the prose of the third wave of Ukrainian modernism reveals a clear correlation between the complicated complex of socio-cultural factors and the immanent features of the development of the domestic and foreign literary processes including the individual identity of the creative voices. The image of a woman in the prose of the 1920s acquires a new humanistic depth, it is enriched with new moral content. It is relatively easy to see the attempt of the writers to link a woman and the earth, a woman and the eternity of life. Therefore, it embodies the vitalistic power of the revived Ukrainian people. According to Y. Sherek: "Eternal youth, eternal fruitfulness, eternal purity, eternal life, and eternal Ukraine are the contents of this image" 3 . The heroines of the works of Ivan Dniprovsky (Anathema from the writer's eponymous work), Mykola Khvylovy (Sister Katrya from the "Sanatorium Zone", Bianca from the "Sentimental Story"), Yuri Yanovsky (Natalka from the "Four Sabres", Tayah from the "Ship Master") are the epitome of the author's ideal and the embodiment of eternal vitalistic power and national spirit. They are elevated to the level of the cult of women as revolutionaries, sisters, mistresses, and mothers. They are associated with duality and creativity. Often the archetypal figure of the mother in the prose of the Ukrainian modernists is not associated with the individual, but rather it is a universal type of womanhood that symbolizes Mother Earth. The identity of this goddess is used by the authors, thuss, a specific woman is irrelevant. For a man, she is a

\footnotetext{
${ }^{2}$ Історія европейської ментальности / За ред. Петера Дінцельбахера / Переклав 3 німецької Володимир Кам'янець. Львів : Літопис, 2004. С. 132.

3 Шерех Юрій. Колір нестримних палахтінь (“Вертеп” Аркадія Любченка) // Любченко Аркадій. Вибрані твори / Передм. Л. Пізнюк. Київ : Смолоскип, 1999. C. 489.
} 
saint, holy, the goddess that arouses all his sexuality. This is the peculiarity of the female motif in "Arabeski" and "Sentimental Story" by M. Khvylovy, in "Four Sabers" and "Ship Master" by Y. Yanovsky, in "Naiada" and "For Her" by I. Dniprovsky and others.

Among the main three hypostases, which are girl, woman, mother, the latter one is always the most attractive in the male literature. Thus, in the figuratively symbolic vision of Mykola Khvylovy, the young girl's virginity is a boundary state not only of the heroine herself but also, more broadly, of his modern age. It is one of the semantically expressive metaphorical images that characterizes the concept of "romanticism of Vitaism", in particular, the idea of a vitalistic law of life, according to which there is nothing frozen, holy, absolute, all is subject to the law of motion, transformation, birth, and extinction. In the opposition "male-female", which in the psychological discourse corresponds to the essence of "conscious- unconscious", the most unconscious, irrational, feminine principle is raised. The best heroines of M. Khvylovy are full of the noblest impulses to the cultural and intellectual tops, and at the same time, they dream of motherhood. For example, Bianca from "Sentimental Story" seeks to become a full-fledged recipient of the most active social life and, at the same time, her soul is filled with existential longings associated with the power of the instinct of motherhood: "I wanted to be a mother back then, and the wind embarrassed me: I (though it is ridiculous!) wanted to get pregnant, as a blue sky got pregnant, which for millions of centuries has kept the secret of the most beautiful and pure conception "4. As the text of the story confirms, it can be viewed as the discourse of desire which "is connected with the discourse of the existential, since according to the author, it expresses the basic meaning of life, the philosophy of human existence which is the continuation of the human race"s.

According to world mythology, the feminine is primary, whereas male creation is secondary, which only emerges later. At first, a woman appears, and afterward, the man is born. A woman lives as an eternal, self-sufficient, unchanging creature. In particular, such discourse is read in the novel "Ship Master" by Yuri Yanovsky. A striking example is an artistically painted picture of childbirth which symbolizes vitalistic power, eternal fertility, and virgin maternal purity: "After that, we saw how a woman gives birth. Her legs, bruised with pain, tremble, and her full belly trembles. Here is what we have invariable since the first years of human development and it will never be transferred or facilitated. A daily reminder of those colossal spaces that humanity has crossed over.

\footnotetext{
${ }_{5}^{4}$ Хвильовий М. Твори: У 2 томах. Київ : Дніпро, 1990. Т. 1. С. 275.

5 Гундорова Тамара. Проявлення слова. Дискурсія раннього українського модернізму. Постмодерна інтерпретація. Київ : Літопис, 1997. С. 187.
} 
The woman begins to give birth. Oh the holiest joy of having a baby!

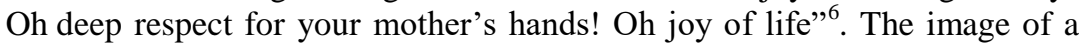
female mother is associated with the soil, fertility, vegetation. As Plato pointed out, it is not the earth that imitates the woman that is pregnant and gives birth, but the woman is the earth. A similar interpretation is evident in Yanovsky's artistic discourse. "I feel like a steppe, into which grain falls and a song of a lark, I feel like a ravine in which the waters pour, I see myself as

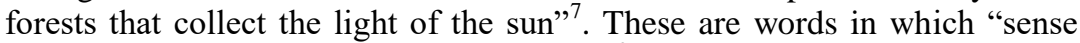
and the mind of a born woman" can be seen ${ }^{8}$, the author gives these words to the heroine, Taiah, of the novel "Ship Master".

The woman is viewed as a symbol of humanity, the highest form of consciousness in which lies the desire for the future, which leads to perfection. The authors created the events and characters from the "nature of everyday life" to avoid abstract figures. In the prose of the 1920s, the mother archetype becomes concrete and social; according to a deep ethnocultural tradition in a number of works, it can be seen as a metaphor for Ukraine ("I (Romance)", "Mother" by M. Khvylovy, "Four Sabers", "Ship Master" by Y. Yanovsky, "Wolf Ravines" by V. Vrazhlyv, and "Without Soil" by G. Epic, etc.).

Many literary studies have been devoted to the problem of the specifics of female images in Ukrainian literature of this era. In this connection, it is expedient to mention Arkady Lyubchenko's apt statement about special features of character formation and modeling of a woman's type in the works of Mykola Khvylovy, which also applies to the prose of "romanticism of Vitaism" as a whole: “... she is young, for the most part, delves into something distant, the unknown, she is dissatisfied with being modern because it disappoints her, depresses her; her nature is romantic; softness, gentleness, tenderness, heartiness, warmth; her soul is still in buds; naivety, proximity, low intellectual level, provincialism, domesticity, primitiveness. However, she possesses inoffensiveness, fine makings on healthy fresh soil, significant positive possibilities, innate nobility; if circumstances were favorable, if it were to be brought up properly, then something very interesting, valuable, significant would come out"9.

Actually, in the artistic discourse of "romantic-vitaism", the type of "new woman" is realized, in which the power that is able to save and renew the

\footnotetext{
${ }^{6}$ Яновський Ю. Твори: В 5 томах. Київ : Дніпро, 1983. Т. 2. С. 10.

${ }^{7}$ Ibid., c. 90 .

${ }^{8}$ Ibid.

9 Любченко А. Спогади про Хвильового. Ваплітянський збірник. Видання друге, доповнене, під редакцією Юрія Луцького. Едмонтон : Мозаїка, 1977. С. 45.
} 
world is asserted. Writers also portray a "natural" unconscious woman, as well as a woman who has an aristocratic spirit because, according to $\mathrm{N}$. Zborovskaya, the most conscious, intellectual woman "opened the perspective of national-spiritual courage" ${ }^{10}$.

The female motif in the fiction of the 1920s is most closely associated with the motif of the "Asian Renaissance" and is projected into a dichotomy which is birth, creation/creative impotence, "twilight". The ideal of a woman was influenced by the idea of the cyclical nature of the culture and the messianic role of Ukraine in a number of radical transformations of Europe and the idea of reviving the Faustian spirit of knowledge on the national soil and so on. Writers poetize in their own works and uplift the cult of a new woman who, thanks to her excellent psyche, is able to create new values in the realm of material and spiritual culture that a man is not able to make.

In the prose of Mykola Khvylovy, Yuriy Yanovsky, Ivan Dniprovsky, Julian Shpol, and many other writers of the 1920s, the issue of the destruction of traditional gender roles, the longing for just world order, and the "new person" characteristic of the national revival era are being raised. The image of "a non-patriarchal woman somehow fits into a cohort of new heroes who were supposed to represent a complete break with an unacceptable tradition, the affirmation of a new morality, a new art, a new way of life, in general, they were found in an incredible situation when the world seemed to get back to square one" 11 .

The eternal pursuit of a higher harmony, which creates a unique personality, is truly crucial to the vitaistical verbal-figurative art. The era of "romanticism of Vitaism" needed its meaningful "filling" of personality, namely its heroic constructive psyche, rejuvenation of the Faustian spirit of knowledge, and creative, gifted, talented nature, etc. Hence, the search for new approaches appears that reflects male and female cultural experiences in a vibrant movement towards harmony and the understanding of the problems of interaction between character and gender, and so on. Therefore a number of heroines were created (Bianca from the story "Sentimental Story", Aglaia from the novel "Valdshnepy" by M. Khvylovy, Taiach from the novel "Ship Master" by Y. Yanovsky, Kirka from the work "Golden Little Foxes" by Y. Shpolo, etc.); they are presented as romantic characters, "new generation people", autonomous, self-sufficient and strong women who saw themselves as creators of a fair world order.

10 Зборовська Н. Феміністичні роздуми. На карнавалі мертвих поцілунків. Львів : Літопис, 1999. С. 311.

${ }^{11}$ Агеєва В. Жіночий простір: Феміністичний дискурс українського модернізму. Київ : Факт, 2003. С. 256. 
After all, the artists of the Ukrainian Renaissance sought to think not in the standard way, but to seek out in the word, as Y. Yanovsky notes, "new understandings, and new content" [I, 38]. Their creativity is a powerfully rhetorical, self-explanatory thought that often becomes a constructor of artistic language.

The movement of the nation to its "Golden Age", to the epoch of Asian Renaissance (which will come in about 200 years, according to Khvylovy) is a process that included a series of stages. Each stage is marked by the appearance of qualitatively new features of the Ukrainian word and its enrichment and complications, improvement of psychological and intonation nuances.

The first signs of this movement are manifested in revolutionary transformations, in the destruction of existing culture and the renewal of the world, in the rebirth of life and space after its aging. Twilight of Europe, the collapse of the Russian Empire evoked a "metaphysical horror" initially. After all, the contemporaries witnessed the tragedy of a civilized, mechanized and established in its natural (feminine!) foundations of the world. This period of social development has a masculine character and is endowed with the features of physicality, masculinity, technocentrism and violence. In such a way, the heroines of fictional prose of the 1920s emerged and they are strong, self-sufficient, non-patriarchal women.

\section{Sexuality, Love and Vitaism in the Artistic Interpretation of Ukrainian Modernists of the 1920s}

The issue of the constant and the variable, the continuous and intermittent in the attitude of people towards sexuality and love is discussed on the pages of the work of "The Nativity Play" by Arkady Lyubchenko. A striking example is "The Puppet Action or the Rebellion of Blood", with "its two disputants at the beginning of the section and a boy and a girl at the end"12. The dialogue between two middle-aged men is conducted in a system of philosophical and moral-ethical coordinates that are established by the author. Therefore, it supports the writer's super-task which is to create a philosophical-generalizing subtext. The interlocutors go and discuss the lecture "Our Reality and the Problem of Gender" which was delivered by a visiting Distinguished Professor of Aesthetics and Morality.

As Y. Sherekh points out, Lyubchenko created "conditionallypuppetlike" characters, ie "they are people, but they are clearly schematized, transformed into dolls, into mouthpieces of certain ideas or views, or just to

\footnotetext{
12 Любченко А. Вибрані твори / Передмова Лесі Пізнюк. Київ : Смолоскип, 1999.
} C. 475 . 
prove a certain thesis". Their most logical reasoning is about the age-old "problem of gender" which is "that organic difference that divides humanity into men and women" $" 13$, and it is entirely projected to the present.

Two middle-aged people cannot agree and passionately defend their views. One of them is sharply ironic, sarcastically displaying the most unattractive phenomena of a renewed being, which, he notes, "people unleashed all the gripes of morality, especially the youth, that they turned a human being into some carnal monster... they allowed to trample the laws and ethics, to give unlimited freedom to emotions, to return to the original polygamy, to become great fornicators" ${ }^{14}$. In addition, while referring to his own experience in medicine, the man argues that sexual encounters adversely affect the entire human body, especially of a young person, as such encounters significantly disrupt all biological functions. He criticizes views of love as a passion, denies sexuality as a natural force, because he sees the main purpose of sexual intercourse as a procreation.

Instead, the other speaker (whose views largely reflect the author's attitude to gender and sexual self-awareness) offers a well-thought-out and reasoned alternative to interpreting gender roles in society. He notes, in particular, that "the days of Juliet are past", and in the age of new psychological shifts, a woman is simply different "and above all, she is not a Juliet, but a socio-biological entity"15. The hero justifies this statement basing it on the Ukrainian socio-cultural situation. After all, he notes that the social revival itself inspired the realization of the ideas of emancipation. "For when other nations have spent a lot of their potential by nominating one or the other finished female type, we, specifically us, have largely retained that potency. Because we still have so much unprecedented freshness, because our woman will now go to the world for the first time, because our woman is in the happiest coincidence, because our woman will not be brought to this position by some gouty hand of the past, but by a strong, confident hand of the great today"16.

The problem of juxtaposing the images of "a man" and "a woman" in the public consciousness and presenting a woman as an inferior and less valuable being, arises for the reader differently in contrast to the usual image of a woman in which the women's interests and social roles are customary for the patriarchal society. In the artistic discourse of A. Lyubchenko, the

\footnotetext{
${ }^{13}$ Любченко А. Вибрані твори / Передмова Лесі Пізнюк. Київ : Смолоскип, 1999. C. 301.

${ }^{14}$ Ibid., c. 303.

${ }^{15}$ Ibid., c. 311.

${ }^{16}$ Ibid., c. 313.
} 
woman is given the role of forming and modeling, in other words, her role is cultural and Apollonian.

The protagonist denies the traditional notion that a woman is seen as a lesser valuable being who is organically incapable of being equal to her husband, and her function is reduced to having only a natural biological role. He criticizes such a model of perception of a woman by a man, "when they look at a woman as an ephemeral, demanding, inconsolable creature, or if she is seen as some intricate, secretive animal, or a lower degree animal, an animal unmasked and a cunning animal (and the majority sees her as such) that by nature, she was supposed to hide herself by a delusion of secrets and masquerade of intrigues"17. This emphasizes the social equality of women and men, their ability to realize themselves in public life, and at the same time recognizes the power of the blind instinct of nature, the purpose of which is in the continuation of a humankind.

A. Lyubchenko speaks about the equal natural rights of men and women as individuals through the mouth of one of the heroes of the work. "I hope you will not deny that she, like us, has everything from genius to atavism. And above all, like us, there is a rebellion of blood "18, he points out as a representative of men.

As Y. Sherek rightly notes, "biological attraction of gender, from which the theme of youth, the theme of woman, the theme of motherhood, the theme of birth of man, generation, people emerge" is under the "microscope" of Lyubchenko-prose writer ${ }^{19}$. In fact, in the author's discourse, the modern ideal of a woman is formed on the basis of social restructuring, and this idea is akin to the classic Tychyna's ideal of the "brave intelligent Madonna". In the world of Ukrainian prose, it unfolds as a synthesis of a beloved, mother, friend, and wife. The power of a new woman is seen in her biological nature, specifically in the power of maternal impulse, in the "rebellion of blood", and in the realization of the right which is to be the creator of one's life and to nurture herself as a fully-fledged culturally, nationally conscious modern personality.

One of the heroes of "The Nativity Play" by A. Lyubchenko states that inevitably, "by having overcome the addiction, a new woman will come",

\footnotetext{
C. 311.

${ }^{18}$ Ibid., c. 314.

${ }^{19}$ Шерех Юрій. Колір нестримних палахтінь (“Вертеп” Аркадія Любченка). Любченко Аркадій. Вибрані твори / Передмова Л. Пізнюк. Київ : Смолоскип, 1999. C. 470.
}

17 Любченко А. Вибрані твори / Передмова Лесі Пізнюк. Київ : Смолоскип, 1999. 
and "then the beauty of birth, the beauty of motherhood will become a basis of a relationship" 20 .

The era of "city wars" evicts a warrior who is a fighter with chaos. And a woman is valued first and foremost because of her brave spirit, vitalistic power and strong-will. Thus, in the story of "Anathema" by I. Dniprovsky, it is relatively easy to see the attempt to connect a woman with the revolution and the creation of the future. The author constantly emphasizes Anathema's stoutness, her courage, her prowess, her willpower, and her vibrant energy. The heroine is the Chekist, who is viewed as "the terrible Anathema who shook the whole city", when needed, she could take "her nerves in her fist and she was ready again" 21 . In her childhood, her name was Tyoma. "This bourgeois-sweet name was jokingly changed by her friends to Tema. In the cellars to which she drove the hiss of the townspeople, she was called Anathema. This name was raunchy, smelled of nights, of the cunning detectives' interrogations, of relentless punishment. She liked this name and it turned into her party name. Even the closest colleagues forgot her real name, she came off of her like a button of a dress and got lost on the dusty roads of the Chekist"22.

The focus on revolutionary duty transforms Anathema into an exceptionally whole person who uses everything to achieve the main goal. It is not an accident that there is an erotic motive in Dniprovsky's text. After all, eros is not only a sexual attraction but also a manifestation of selfpreservation, a love for people, creativity, and peace. Eroticism is closely linked to the notion of life, which in the author's discourse is interpreted as "life power", "stamina", "vitality", as well as, "perspective" which is an attitude of looking forward to the future opportunities. Anathema, who repeatedly looked in the face of death, each time testified that death was "beautiful only in books" 23 . Therefore, when imprisoned, she tries to escape from the shackles of executors at any cost.

The author enhances the heroism of the heroine with the erotic-biological aspect of the image. The "three counterrevolutionaries" who interrogated Anathema were charmed by her, "and a strange, predatory curiosity flowed from their wide, still eyes" ${ }^{24}$. In depicting this moment, I. Dniprovsky uses the principle of reflection, when events are described not directly, but through the perception of the heroine herself, in her reflections. The author

20 Любченко А. Вибрані твори / Передмова Лесі Пізнюк. Київ : Смолоскип, 1999. C. 313.

${ }^{21}$ Дніпровський І. Яблуневий полон: Вибрані твори / Упорядкування, передмова Михайла Наєнка. Київ : Дніпро, 1985. С. 309.

${ }^{22}$ Ibid., c. 309.

${ }^{23}$ Ibid., c. 324.

${ }^{24}$ Ibid., c. 335. 
skillfully uses the possibilities of the monologue, avoiding the description of certain things, instead hinting at them. Anathema knew that she had one gift from nature which was her black luxurious hair, and it made her "ominously beautiful" (David's expression). Even trimmed, it lay over her clever clean forehead like a two-week-old lamb... All her "nine car-locomotive loves" began from her head ${ }^{25}$. A woman uses her sexual attraction with an ideologically motivated, completely rationalistic goal to avert suspicion of "counter".

At the same time, Anathema is ready to face death with dignity, because she realized that "he who is not afraid to kill people must be ready to stand fearlessly under the muzzle"26, because "such is the dialectic of death"27.

The "new woman" with a weapon in her hands illustrated the nihilistic denial of everything old, including what can be called the traditional division of gender roles. They had to overcome their connection with tradition, to tear the umbilical cord, which binds them to the family and to mother nature through the novel understanding of the cultural, modern dimension of movement and progress (Bianca remarks in Mykola Khvylovy's "Sentimental Story": "I could not return to the province, and no Rousseau could attract me with rural landscapes" ${ }^{28}$ ). In other words, Ukrainian conquistadors say goodbye to the past in order to build a bright future. As M. Khvylovy's heroine remarks, the whole tragedy was that they were born as people of their time, who passionately believed in the "blue horizon". Bianca says, "I thought about the bizarre horizon that drew me from my homeland... I believed that I would meet some great man in Z, and then a miracle would happen" ${ }^{29}$. An individual lives in the "future" and he/she sacrifices himself/herself and the loved ones for the future. From the point of view of "the whole truth", "whole life", modernity in the fiction of the 20 s is understood as a moment, a "checkmark", and, accordingly, the age of an individual is "as short as a sparrow's beak" $"$.

The destruction of family relations, the terrible mutation of the human race, the break with tradition and naturalness are the signs of the transitional existence of modern Ukraine. The "new people" are aware of the absolute value of the future and the relative value of their own personality, consciously sacrificing their earthly lives for the sake of an ideal future.

${ }^{25}$ Дніпровський І. Яблуневий полон: Вибрані твори / Упорядкування, передмова Михайла Наєнка. Київ : Дніпро, 1985. С. 335.

${ }^{26}$ Ibid., c. 328 .

${ }^{27}$ Ibid., c. 328.

${ }^{28}$ Хвильовий М. Твори: У 2 томах. Київ : Дніпро, 1990. Т. 1. С. 508.

${ }^{29}$ Ibid., c. 491.

${ }^{30}$ Ibid., c. 490 . 
The writer recreates the existence of a person in his/her constant pursuit of "future", which guides the inner movement of the fighter-vitalist, in order to show the revolutionary transformations in society as a transition to the new, without the pursuit there is no movement and progress. In the artist's understanding, "world fires" express the need to comprehend events and develop elements of a new understanding of the world.

Communards, fighters for the "unknown fantastic land" will be replaced by a qualitatively different generation of people who will be the heirs of spiritual experience, whose inner world will be transformed and made perfect. This is a natural manifestation of the law of cyclical historical and cultural development of society. The integrity and vitalistic power of such heroes is always emphasized. Comrade Ulyana, who is the heroine of M. Khvylovy's story "Sentimental Story", says: "Even physically, they were exemplary people" 31 .

The constitution of "trans-reality" in the prose of the "romantics of vitalism" occurs through an emphasized volitional projection of the individual "I", which correlates with male discourse. Also, this intention affects female characters. Not only the volitional integrity is emphasized, but also the natural, living force of the heroines, which is also manifested in their appearance can be seen in works "Sentimental Story", "Waldshnepy" by M. Khvylovy, "Four Sabers", "Ship Master" by Y. Yanovsky, "Anathema", "Nayada" by I. Dniprovsky, "Earth" by O. Dovzhenko and others. For example, Bianca from Khvylovy's "Sentimental Story" appears not only as an intellectually developed person, but also as a physically beautiful woman. For an exemplary new person, values are everything that enhances the vital force of life, including beauty, and intelligence, "including youth, and sexual innocence" ${ }^{32}$.

Bianca is free from many patriarchal stereotypes. Having a strong-willed whole nature, she tries to harmonize her spiritual and physical needs, giving up hypocrisy. And Chargara provokes such a step. The heroine unequivocally offers her body to the artist. Chargarov is impressed by the naturalness of desires, simplicity, ease, even the "mauvais tone" of a girl, and when "bourgeois conventionality" is neglected which is the established inequality of the sexes, that "does not allow a woman to be the first to talk about love" 33 . In such "provocative" moments, her power over her husband is revealed, and she herself resembles a player. Bianca challenges her "manicured age": "I remembered the prince's tower and Yaroslavna,

\footnotetext{
${ }^{31}$ Хвильовий М. Твори: У 2 томах. Київ : Дніпро, 1990. Т. 1. С. 502.

${ }^{32}$ Ibid., c. 505.

${ }^{33}$ Ibid., c. 506.
} 
and I remembered such clean and good Turgenev's women and I thought that there would never be such women and that even I, who did not know any man yet, even I have lost my purity and my innocence long time ago" ${ }^{34}$.

The author constantly emphasizes the vitalistic power and values of the heroine. The artist Chargar sees "something predatory and deprave" in Bianca. The girl's outward beauty was particularly contrasting with the emphasized physical imperfections of Cook, an "aged and immoral bachelor" with "little olive eyes" who courted her. The vitalistic meaning of this opposition is hidden in the justification of the right of another strong man (such as the artist Chargar) to take such a woman and to take her for the sake of procreation: "He said that he was very disturbed by the innocence and not only because a male is awaken but primarily because the artist wakes up as well" ${ }^{35}$. This state of love in the philosophical system of Plato ("Phaedra") is interpreted as the friendship of two lovers.

The work constantly focuses on the "kinship of souls" of Bianca and the "famous painter" of the country. They were bound by the spiritual measure of understanding that was reached in communication. Such relationships are nourished by Platonic love, the meaning of which is the creation of the beautiful, what is referred to as a "blue fairy tale", a transreal world.

The heroinees inappropriate behavior and the will to live are a "necessary and completely natural stage" on the way to a natural person, in which corporeality and spirituality are harmoniously combined. According to Khvylovy, the dilemma of the natural and the intellectual cannot be resolved in favor of one or the other. Also, Chargar is not an immoralist and a natural man who is a subject only to the power of instinct. As the author claims, at first he rejects physiological love, trying to imitate the Platonic idea of spiritual love. But later, when he is exhausted by doubts and disharmony, he realizes that it is impossible to separate the spiritual from the corporeal. Obeying the power of instinct, Chargar overcomes his indecision and decides to have an intimate relationship with Bianca. But he is late as Bianca surrenders to Cook.

The relationship between Bianca and Chargar can be seen as a discourse of ideal communication based on Platonic disembodied love. There is a spiritual measure of understanding between the heroes in love, which, according to Diotima ("Symposium" by Plato), is a transcendent request which is the guide and the path to knowledge. Therefore, in its essence, such request is the creation of the beauty which is the "superior" reality... Diotima is the personification of the female voice in Plato. She denies the procreative

\footnotetext{
${ }^{34}$ Хвильовий М. Твори: У 2 томах. Київ : Дніпро, 1990. Т.1. С. 508.

${ }^{35}$ Ibid., c. 499.
} 
function of love (and lovers) and that love is the way to achieve immortality in the descendants. Instead, she speaks of the will to beauty, which realizes itself in love, and this love generates both discourse (language) and wisdom (knowledge-philosophy)" ${ }^{\prime 36}$. The theme of love and sexuality is central in the modern discourse of I. Dniprovsky's prose. In all the stories included in the collection "For Her Sake" (the exception is "Valley of Eels"), a woman and a man are the protagonists. And this is natural, because, as the character of the story "Nayada" (by I. Dniprovsky) notes, even when the "commune and white city" come, humanity will be solving "the problem of crime and the problem of gender". In particular, the author notes that "the first problem will be solved, and one needs to remember about the second problem because the women's problem will hang humanity, and the last sigh of humanity will be on the gallows of the gender" ${ }^{37}$.

I. Dniprovsky uses Freudian techniques to solve the "problem of the eternal appetence of genders". The theme of love is covered entirely in the modern spirit, with emphasis on the sexual nature of this feeling. Therefore, the work is full of both candid scenes and candid conversations. Thus, in the author's text the artist paints an erotic picture in front of his friends: "A young man lies in the field, looks at the blue wings of cornflowers and thinks absolutely nothing... But suddenly, how wheat spikes stand on the field, in about ten feet away... he sees a white waving skirt and white full calves, rustling rye under the sickle ... the girl bends down, and the white skirt jumps up, falls, and the young man catches the eyes of the shape of the girl's knees. He looks and something incomprehensible happens in him... His eyes are muddy, ancient ancestors are raised in his chest... His eyebrows twitch, his hands tremble, the sickle rings thinly in the rye and the skirt jumps up and down... Suddenly some unknown force throws him to his feet. Harvest heard a rustle behind her back which was the horror, the primordial horror of the female, the instinct of self-defense, the struggle of the individual for the right to freely choose a partner and horror took hold in her blue eyes and the sickle rang at her feet. The drunken smell of the field, the drunken smell of a woman's body, hit him in the brain"38. In this scene, eroticism is an element of the vitalistic flow of life.

In the author's interpretation, eroticism acts as a mediator between the natural and the supernatural, the sensual and the supersensible. According to

${ }^{36}$ Гундорова Тамара. Femina melancholica. Стать і культура в гендерній утопії Ольги Кобилянської. Київ : Критика, 2002. С. 51.

${ }^{37}$ Дніпровський І. Яблуневий полон: Вибрані твори / Упорядкування, передмова Михайла Наєнка. Київ : Дніпро, 1985. С. 265.

${ }^{38}$ Ibid., c. 264. 
T. Gundorova, "in modern thinking, eroticism means not only the Platonic illogical path to the absolute, but also the constitution of a new, modern sensuality, where eroticism reveals the urge of the modern subject to the unformed, otherworldly, desacralized idealist who is fixed between opposite feelings and extremes of the soul, and it symbolizes the pursuit of the "new", supported by the sexual desire of the individual" ${ }^{\text {"39 }}$.

In the artistic discourse of Dniprovsky, eroticism performs a cognitive and creative function, it agrees with the natural perfection of life. In addition, as R. Bart noted, it is generally the ontological essence of the deployment and discovery of the "new" existence of the "romance of vitalism".

Contemporary sociological literary criticism, which was based on the principles of Marxism, interpreted the erotic-metaphysical author's discourse unequivocally negatively, calling it "a phantasmagoria of eroticism and religious-mystical madness" $"$. The work by I. Dniprovsky is considered harmful, because they say that the writer does not only bloom a charming woman with "beautiful" romance but also tries to reach suggestion with intense lyricism" "42, but also some sexual fantasies of the heroes allow it "to be concluded that he also lives in the realm of these figurative complexes, in this false, and at the same time naive and ridiculous problem, that this sexual pathos and erotic indulgence of details is not an accidental phenomenon, but some rather expressive elements of his worldview and style"43. Difficult relations between the Chekist and Nayada, landscape sketches associated with vivid love experiences, seemed inconsistent with the example of Marx's interpretation of the essence of a person as "the totality of all social relations". Hence the accusation of the lack of a class worldview in the prose of the writer and a certain ideological incompetence of I. Dniprovsky appeared.

In the deepest sense, the specificity of Dniprovsky's modernist discourse has a Gnostic-metaphysical basis. The author's text reveals its own modernist artistic interpretation of eroticism as a natural, substantial basis of existence. Ivan Dniprovsky tries to analyze the human soul which is characterized as opposite and beyond the control of the mind, unconscious,

\footnotetext{
39 Гундорова Т. Модернізм як еротика “нового” (В. Винниченко i С. Пшибишевський. Слово і час. 2000. № 7. С. 21.

40 Барт Ролан. Удовольствие от текста. Избранные paботы. Семиотика. Поэтика. Москва, 1989. С. 495.

41 Савченко Я. Вертер із партійним квитком. Життя й революиія.1928. № 7. C. 112 .

42 Ibid.

${ }^{43}$ Ibid.
} 
irrational and "sinful". The prose writer is interested in the inner world of a person including women and men and he disregards their affiliation to a particular camp (Bolsheviks, Chekists, White Guards, etc.).

The writer creates a modern character with a differentiated psyche. His male characters, as a captain in "Maria of Joy", a communist in "Fog", a Chekist in "Nayada", are at the break of the inner "I", cause terrible pain and despair. They are the so-called anxious, emotionally unbalanced types of character, who are in constant self-affirmation. The femininity of character inspires the search for spiritual support, which men see in a woman.

In the artistic discourse of I. Dniprovsky, the features of Endymion's motive are clearly traced. The essence of which is the passionate and hopeless love of a young man for an extraordinary and unattainable woman. Symptomatic features of endemicism are evident in the story "Nayada", which is about the fatal love of a Chekist and a beautiful proud woman-aristocrat who by the circumstances falls into the Bolshevik world ("Cleopatra and Nayada", "Charlotte Corde", "Fantasy"). It is clear that endemicism did not play an exceptional role in the work of Dniprovsky, but it allows us to understand the peculiarities of the psyche, artistic thinking of the prose writer.

Erotic subtext accompanies the vicissitudes of the work, and it can be heard in the thoughts of the protagonist. Love and sexuality are the main philosophical question of Nayada and literally, it is a matter of life and death for the KGB. Unexpected love for Nayada splits the whole Bolshevik self, he stubbornly competes with himself, experiencing mental anguish. The hero does not feel ground under his feet, he loses his "absolute" when the enemies of the revolution, mother and daughter, are brought to his office. He saw "something of beast and grace" in the girl. A woman who was a "vamp" stood in front of the Chekist: "A young heroine, a future heterosexual, a lush rose... a mouth is fragrant, odorless, fresh as morning ... overwhelming female beauty. She is not Venus, not Madonna, but just overwhelming beauty ... it just eats into the soul, sucks drop by drop, melts in you and drowns yours like wax... where it passes, there is the family break up, there the brides and the loved ones who die" 44 . In the author's literary text, the motive of the woman-seductress is quite expressive, moreover, not in its biblical sinful interpretation, but it is rooted in mythology. Nervous male thoughts about "charms" and fate are inspired by the feminine attractiveness of the heroine, her extraordinariness.

Seeking to get rid of the captivity of his feelings and experiences, and, at the same time, to show his power over the woman, the Chekist raised his

${ }^{44}$ Дніпровський І. Яблуневий полон: Вибрані твори / Упорядкування, передмова Михайла Наєнка. Київ : Дніпро, 1985. С. 276. 
hand "and hits her in the face with his whole palm"45. However, Nayada, who does not lose her human dignity and retains her identity under any circumstances, emerges victorious from this peculiar duel. For her sake, the Chekist departs from the ideological principles for which he fought because he sees Nayada as a proud, charming, noble, shrouded in the "romance of vitalism" woman. The feeling of love causes the hero terrible torment, intense and painful self-reflection. After all, behind the mask of the ruthless Bolshevik, the Nemesis, by which he was "disgusted to his physical pain", lies the romantic, sensitive soul of a hero who is prone to noble deeds. He knows that he is not an aristocrat, but he fell in love with Nayada so much that he sets free the fierce enemies of the revolution, such as counts, princes, and so on.

The hero seeks an intimate relationship with Nayada, but, at the same time, he lacks the courage to take such a step. He understands that you cannot own this woman, you can only be with her. He stealthily kisses her clothes, as the most expensive relic is kept by the chair on which she sat in Check's office. For him, Nayada is a woman who is "the soul of all conspiracy, the main lever of progress, the musical accompaniment of a tragedy which is called the history of mankind ... Marx put Hegel's dialectic on his head, and the person who will put a woman's dialectic, that person will serve people the most" ${ }^{\text {"46 }}$.

However, happiness that manifests itself only in dreams cannot be lasting. Freed from the Bolshevik massacre, Nayada left Ukraine and went to Poland. Reality always interrupts sweet sleep and inspires disappointment and sadness. The love story of a security officer ends tragically. After accidentally meeting Naiada in Crimea, he dies with her.

The image of the Chekist in the author's discourse represents the type of a modern man as a set of intrapsychological relations. He is strong and weak at the same time, aesthetically vulnerable, free from patriarchal educational, prohibitive and hypocritical morality. The spontaneous will of life, artistically embodied in this image, is one of the symptomatic features of the hero of the new era of modern civilization.

The erotica by Dniprovsky has a distinct vitalistic tinge, the image of Nayada is full of deep piety and imbued with the author's empathy. Here reigns the magical authority of all women. The man in I. Dniprovsky's prose is a neurotic person who is captivated by his feelings and experiences, thoughts, a man with a broken painful psyche. Instead, the characteristic

45 Дніпровський І. Яблуневий полон: Вибрані твори / Упорядкування, передмова Михайла Наєнка. Київ : Дніпро, 1985. С. 276.

${ }^{46}$ Ibid. 
feature of the female figures of the writer's work is the aristocracy of the spirit, nobility and patience, inspired by evil fate, which betrays the sanctity of their body and soul.

I. Dniprovsky's prose is dominated by the type of woman-aristocrat, who intellectually rises above her husband and, at the same time, she often suffers abuse. The suffering of a woman in the author's reception is the most striking, the most painful, the most unjust tragedy in the world. The motive of a woman's aristocracy, self-respect and freedom, the ability to pass with dignity through all the trials imposed by fate is one of the leading and constant interests in the prose of I. Dniprovsky.

\section{CONCLUSION}

Ukrainian writers of the 1920 s tried to overcome the complex of provincialism and tried to establish modern guidelines. If we resort to gender definitions, the transition from the actual culture to civilization gets feminine characteristics in the prose of M. Khvylovy, A. Lyubchenko. I. Dniprovsky, Y. Yanovsky and others. These features are spirituality, femininity, cosmocentrism, and love. The semantics of the "feminine" is identical to anti-authoritarianism, it implies ambivalence, uncertainty, spontaneity, irrationality. However, modernists are far from preserving a purely feminine characteristic of "culture" and endowing "civilization" with masculine features. Evidence of this is the clear destruction of the passive/active opposition as a female/male opposition, and thus, it is the emphasis on the hierarchical relationship between culture and civilization. The Romantics of Vitaism emphasizes the need for a radical modernization of Ukrainian culture, which includes equality between men and women on the path to elitist sophistication, the rejection of the subject's dominance over the object (man over woman or man over nature in general). The high culture of the nation inspires civilizational relations between people and leads a person to integrity.

Attention to the unconscious, separation of the individual from the masses, striving for the ideal, the desire to recreate a harmonious, natural person, the destruction of patriarchal gender roles - all these are the main points of contact that point to a common vector of aesthetic and artistic pursuits of writers of the 1920s.

\section{SUMMARY}

The article discusses the ways of artistic representation of gender mentality in the prose of Ukrainian modernism of the 1920s. In the literature of the third wave of Ukrainian modernism, the problem of gender roles reveals a clear correlation with a complex set of socio-cultural factors, 
immanent features of the development of the domestic and foreign literary processes and the individual identity of creative voices. The image of a woman in the prose of the 1920s acquires a new humanistic depth which is enriched with new moral content.

It has been found that the female motif in the fiction of the 1920s is most closely associated with the motif of the "Asian Renaissance" and is projected into a dichotomy which are birth, creation/creative impotence, and "twilight". The ideal of a woman is determined by the idea of the cyclicality of culture and the messianic role of Ukraine in a number of radical transformations of Europe and the idea of reviving the Faustian spirit of knowledge on the national soil, and so on. It has been investigated that the artistic interpretation of the transition from culture to civilization receives feminine characteristics from the prose of M. Khvylovy, A. Lyubchenko, I. Dniprovsky, Y. Yanovsky and others. Such characteristics are spirituality, femininity, cosmocentrism, and love. The semantics of "feminine" are identical with anti-authoritarianism, it implies ambivalence, uncertainty, spontaneity, and irrationality. The striking destruction of the passive/active opposition as a female/male opposition has been traced in the works, and thus an emphasis on the hierarchical interrelation of culture and civilization was emphasized.

\section{REFERENCES}

1. Агеєва В. Жіночий простір: Феміністичний дискурс українського модернізму. Київ : Факт, 2003. 320 с.

2. Барт Ролан. Удовольствие от текста. Избранные paботы. Семиотика. Поэтика. Москва, 1989. С. 261-282.

3. Гундорова Т. Модернізм як еротика “нового" (В. Винниченко i С. Пшибишевський. Слово i час. 2000. № 7.298 с.

4. Гундорова T. Femina melancholica. Стать і культура в гендерній утопії Ольги Кобилянської. Київ : Критика, 2002. 272 с.

5. Гундорова Т. Проявлення слова. Дискурсія раннього українського модернізму. Постмодерна інтерпретація. Київ : Літопис, 1997. С. 187.

6. Дніпровський I. Яблуневий полон: Вибрані твори / Упорядкування, передмова Михайла Наєнка. Київ : Дніпро, 1985. 359 с.

7. Зборовська Н. Феміністичні роздуми. На карнавалі мертвих поцілунків. Львів: Літопис, 1999. 336 с.

8. Історія европейської ментальности / За ред. Петера Дінцельбахера / Пер. 3 німецької Володимира Кам'янця. Львів : Літопис, 2004. 720 c.

9. Любченко А. Вибрані твори / Передмова Л. Пізнюк. Київ : Смолоскип, 1999. $520 \mathrm{c}$. 
10. Любченко А. Спогади про Хвильового. Ваплітянський збірник. Видання друге, доповнене, під редакцією Юрія Луцького. Едмонтон: Мозаїка, 1977. С. 33-46.

11. Савченко Я. Вертер із партійним квитком. Життя ц̌ революиія. 1928. № 7. С. 109-118.

12. Хвильовий М. Твори: У 2 томах. Київ : Дніпро, 1990. Т. 1. 650 с.

13. Шерех Юрій. Колір нестримних палахтінь (“Вертеп” Аркадія Любченка). Любченко Аркадій. Вибрані твори / Передмова Лесі Пізнюк. Київ : Смолоскип, 1999. С. 459-497.

14. Яновський Ю. Твори : В 5 томах. Київ : Дніпро, 1983. Т. 2. 424 с.

\section{Information about the author:}

Kavun L. I., Doctor of Philology, Professor at the Department of Ukrainian Literatures and Comparative Studies, Institute of Philology, Bohdan Khmelnytsky National University of Cherkasy 55, Hreshchatyk str., apt. 77, Cherkasy, 18031, Ukraine ORCID ID: https://orcid.org/0000-0002-2782-7521 